\title{
STERILIZATION OF INTRA-OCULAR ACRYLIC LENS PROSTHESES WITH ULTRA-VIOLET RAYS*
}

BY

\author{
C. D. BINKHORST AND F. P. FLU
}

\section{St. Elisabeth Hospital, Sluiskil, Netherlands}

ONE of the problems arising with the use of intra-ocular lens prostheses is that of sterilization. The acrylic lens described by Ridley (1952), as well as the anterior chamber prostheses of Strampelli (1955), Scharf (1955), and Schreck (1955), are made out of polymethylmethacrylate. Heating this material above $70^{\circ} \mathrm{C}$. may deform it, which means that this method of sterilization is not possible. Chemicals affecting the polymethylmethacrylate, like alcohol, formol, etc., cannot be used as sterilizing agents. Ridley (1952) decided to use cetrimide, one of the quaternary ammonium compounds, which does not affect the lens material. Immersion for one hour in a 1 per cent. solution of a quaternary ammonium compound, followed by rinsing in distilled water, has become the generally accepted method of sterilization.

As a rule some inflammatory reaction of the uvea occurs after the insertion of an acrylic lens prosthesis. Many authors, however, describe a far more serious post-operative reaction pattern. Its possible causes were discussed by Binkhorst $(1956 \mathrm{a}, \mathrm{b})$ : one of them, undoubtedly, is the sterilization of the acrylic lens in a quaternary ammonium compound, as traces of this chemical cause toxic irritation. Goldmann (1955) has pointed out that it is impossible to eliminate all traces of this surface active disinfectant by rinsing the lens in distilled water. This fact becomes even clearer upon the realization that a Ridley lens can absorb about 1 per cent. of its own weight of fluid. Gilkes (1956), one of Ridley's associates, immersed a Ridley lens in a 1 per cent. solution of cetrimide for one hour, and then rinsed it in distilled water. Finally he submerged the lens for one week in a volume of distilled water equal to that of the anterior chamber. In this latter volume he measured the increase of electrical conductivity, and found it to be equal to a 0.01 per cent. solution of cetrimide.

The methods of sterilization of intra-ocular lens prostheses have changed but little in the past few years. Some ophthalmic surgeons decreased the time during which the lens was immersed in the disinfectant, and found post-operative uveitis to be favourably affected (Miller, 1953), and others (Rintelen and Saubermann, 1956) prolonged the rinsing. Scharf (1955) 
avoids the quaternary ammonium compounds altogether, and places the prostheses in a streptomycin-penicillin solution.

We feel that all toxic disinfectants must be avoided, and that the results of acrylic lens implantations may thus be greatly improved. Our own experience with Ridley's operation as well as with the insertion of acrylic lenses into the anterior chamber proves our point (Binkhorst, 1956a, b).

To sterilize the prostheses we used the bactericidal action of ultra-violet rays with a wavelength of $2537 \AA$. For this a special apparatus was devised (Fig. 1).

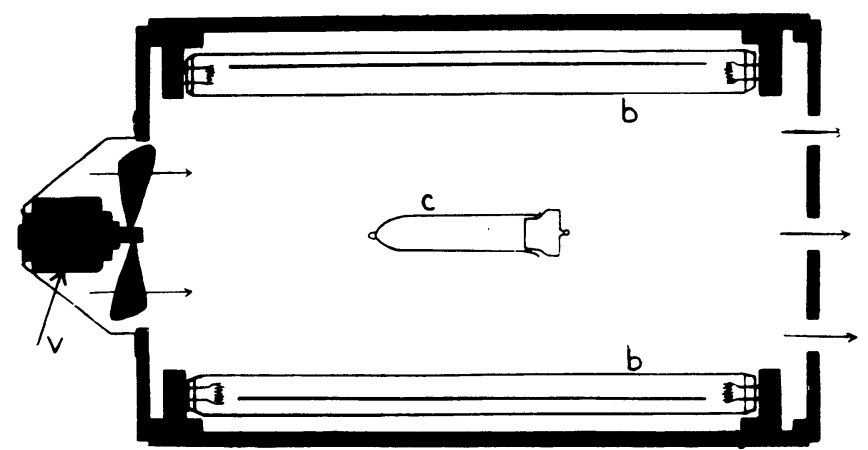

FIG. 1.- Horizontal section of apparatus designed for the sterilization of acrylic lens prostheses with ultra-violet irradiation (fixation of the quartz cuvette cannot be visualized).

A quartz tube, $10-\mathrm{cm}$. long, is provided with an airtight quartz stopper. This quartz cuvette $(c)$ can be snapped into place on clamps in a cylindrical box. The box is $50 \mathrm{~cm}$. long and has a diameter of $30 \mathrm{~cm}$. In the horizontal plane are mounted two mercury vapour bulbs (T.U.V. 15 watt, Philips) $(b)$. The quartz cuvette, which does not absorb the ultra-violet rays, hangs midway between the two lamps, at a distance of $10 \mathrm{~cm}$. The box can be opened at one end to allow the introduction of the cuvette. The inner surface of the box is lined with aluminium foil. This reflects more than 70 per cent. of the incident ultra-violet rays. This set-up guarantees an all-around irradiation and eliminates shadow formation. To prevent a rise in temperature during use, we perforated both ends of the box, and mounted a ventilating fan $(v)$ into one end.

The acrylic lens that is to be sterilized is placed into the quartz cuvette, and is irradiated for $30 \mathrm{~min}$. at room temperature. About 90 per cent. of the radiations of the T.U.V. bulbs have a wavelength of $2537 \AA$, and therefore almost maximal bactericidal action (Fig. 2, opposite). At a distance of $10 \mathrm{~cm}$., one 15-watt T.U.V. bulb furnishes $1 \mathrm{~m}$.watt radiant energy per sq. cm. (Wilgen, 1955). Thus, in this apparatus, and discounting the amplification due to the aluminium reflector, we may expect a dosage of about 3,600 m.watt sec./sq. cm. on exposure for 30 minutes.

The lethal dose for most pathogenic organisms varies from 1 to $50 \mathrm{~m}$.watt sec./sq. cm., exceptionally resistant moulds requiring about $300 \mathrm{~m}$.watt $\mathrm{sec}$./sq. $\mathrm{cm}$. These figures indicate that 30 minutes of irradiation in our apparatus should be sufficiently safe. We verified this in our own experiments, in which not only was the minimal lethal irradiation time determined, 


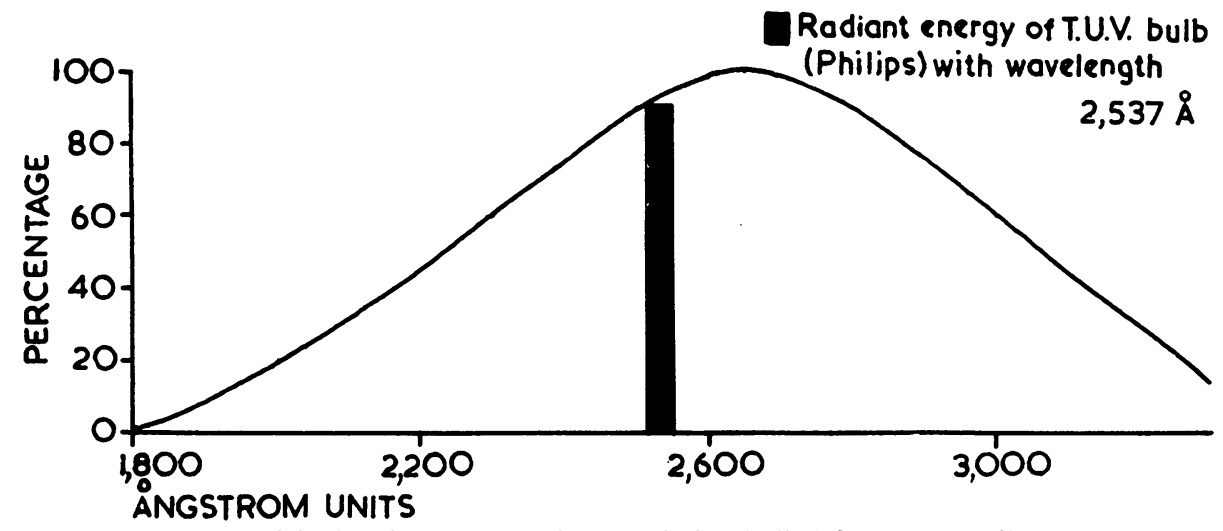

FIG. 2.-Bactericidal action of ultra-violet radiation bulb (after J. van Wilgen, 1955).

but also the possible occurrence of a lag phase was investigated by preparing subcultures.

For this purpose we infected pieces of polymethylmethacrylate with bacterial suspensions from 24-hr strains, containing $3 \times 10^{9}$ bacteria per $\mathrm{ml}$. Other pieces were infected with a culture of an undetermined mould. These fragments were exposed in the quartz cuvette to increasing doses of radiation, and incubated in a suitable medium. If no growth occurred, subcultures were prepared after 24 and $48 \mathrm{hrs}$. The results still being negative after $72 \mathrm{hrs}$, we assumed that the bacteria were not in a lag phase, but killed by the irradiation. The Table shows which micro-organisms were used in the experiments, and the influence of the irradiation time on their growth. The upper figures indicate the tests carried out, and the lower italic figures the positive cultures obtained.

TABLE

EFFECTS OF IRRADIATION ON MICRO-ORGANISMS

\begin{tabular}{|c|c|c|c|c|c|c|c|c|c|c|c|c|c|c|c|c|}
\hline $\begin{array}{l}\text { Irradiation } \\
\text { Time (min.) }\end{array}$ & 10 & 11 & 12 & 13 & 14 & 15 & 16 & 17 & 18 & 19 & 20 & 21 & 22 & 23 & 24 & 25 \\
\hline $\begin{array}{l}\text { Micrococcus .. } \\
\text { pyogenes aureus }\end{array}$ & $\begin{array}{l}10 \\
10\end{array}$ & $\begin{array}{l}10 \\
10\end{array}$ & $\begin{array}{l}10 \\
10\end{array}$ & $\begin{array}{l}10 \\
10\end{array}$ & $\begin{array}{l}10 \\
10\end{array}$ & $\begin{array}{r}10 \\
8\end{array}$ & $\begin{array}{r}20 \\
1\end{array}$ & $\begin{array}{r}20 \\
0\end{array}$ & $\begin{array}{r}20 \\
0\end{array}$ & $\begin{array}{r}20 \\
0\end{array}$ & & & & & & \\
\hline $\begin{array}{l}\text { Streptococcus } \\
\text { pyogenes }\end{array}$ & $\begin{array}{l}10 \\
10\end{array}$ & $\begin{array}{l}10 \\
10\end{array}$ & $\begin{array}{l}10 \\
10\end{array}$ & $\begin{array}{l}10 \\
10\end{array}$ & $\begin{array}{l}10 \\
10\end{array}$ & $\begin{array}{r}10 \\
4\end{array}$ & $\begin{array}{r}20 \\
0\end{array}$ & $\begin{array}{r}20 \\
0\end{array}$ & $\begin{array}{r}20 \\
0\end{array}$ & & & & & & & \\
\hline E. coli & $\begin{array}{l}10 \\
10\end{array}$ & $\begin{array}{l}10 \\
10\end{array}$ & $\begin{array}{l}10 \\
10\end{array}$ & $\begin{array}{l}10 \\
10\end{array}$ & $\begin{array}{r}10 \\
8\end{array}$ & $\begin{array}{l}20 \\
14\end{array}$ & $\begin{array}{r}20 \\
2\end{array}$ & $\begin{array}{r}20 \\
0\end{array}$ & $\begin{array}{r}20 \\
0\end{array}$ & $\begin{array}{r}20 \\
0\end{array}$ & & & & & & \\
\hline B. subtilis & $\begin{array}{l}10 \\
10\end{array}$ & $\begin{array}{l}10 \\
10\end{array}$ & $\begin{array}{l}10 \\
10\end{array}$ & $\begin{array}{l}10 \\
10\end{array}$ & $\begin{array}{l}10 \\
10\end{array}$ & $\begin{array}{l}10 \\
10\end{array}$ & $\begin{array}{l}10 \\
10\end{array}$ & $\begin{array}{l}10 \\
10\end{array}$ & $\begin{array}{l}10 \\
10\end{array}$ & $\begin{array}{l}10 \\
10\end{array}$ & $\begin{array}{l}10 \\
10\end{array}$ & $\begin{array}{r}10 \\
6\end{array}$ & $\begin{array}{r}20 \\
2\end{array}$ & $\begin{array}{r}20 \\
O\end{array}$ & $\begin{array}{r}20 \\
0\end{array}$ & $\begin{array}{r}20 \\
0\end{array}$ \\
\hline Mould & $\begin{array}{l}10 \\
10\end{array}$ & $\begin{array}{l}10 \\
10\end{array}$ & $\begin{array}{l}10 \\
10\end{array}$ & $\begin{array}{l}10 \\
10\end{array}$ & $\begin{array}{l}10 \\
10\end{array}$ & $\begin{array}{l}10 \\
10\end{array}$ & $\begin{array}{l}10 \\
10\end{array}$ & $\begin{array}{l}10 \\
10\end{array}$ & $\begin{array}{l}10 \\
10\end{array}$ & $\begin{array}{l}10 \\
10\end{array}$ & $\begin{array}{l}10 \\
10\end{array}$ & $\begin{array}{r}10 \\
2\end{array}$ & $\begin{array}{r}20 \\
1\end{array}$ & $\begin{array}{r}20 \\
0\end{array}$ & $\begin{array}{r}20 \\
0\end{array}$ & $\begin{array}{r}20 \\
0\end{array}$ \\
\hline
\end{tabular}

Our experiments required greater minimal lethal irradiation doses than those stated for these micro-organisms in the literature. This was to be expected, as our pieces of acrylate were embedded in either bacterial or mould suspensions. Irradiation for 30 minutes in the apparatus described above proved to be absolutely safe. As we never encountered growth on secondary incubation whenever the primary culture remained negative, we cannot exclude the occurrence of a lag phase. 
Finally we ought to consider whether this method of sterilization produces physical or chemical changes in the polymethylmethacrylate, so reducing its usefulness for intra-ocular application.

We noticed a yellow discoloration on exposing the acrylate to ultraviolet irradiation at $50^{\circ}-60^{\circ} \mathrm{C}$. for $12 \mathrm{hrs}$. Irradiation at room temperature did not cause a reduction in spectral transmission. This concurs with experiments done by Frölich (1940). He noticed a significant decrease in spectral transmission, and a roughening of the surface of the acrylate on irradiation with ultra-violet rays at $50^{\circ} \mathrm{C}$. He did not find these changes after long exposures $(500 \mathrm{hrs})$ to ultra-violet rays at room temperature. Therefore, it seems to be of the utmost importance to guard against a rise in temperature when sterilizing with ultra-violet rays. We achieved this by using a ventilating fan.

The low-molecular products formed by this kind of irradiation are also to be considered, as these might become a source of chemical irritation. Although viscosity measurements indicated that the irradiation may fracture the methylmethacrylate chains, $14 \mathrm{hrs}$ ' exposure proved the rate of lowmolecular product formation still to be negligible. Nor need an increase in the content of monomers be feared on our short exposures (Heijboer).

We feel justified in stating, therefore, that sterilization of polymethylmethacrylate prostheses by ultra-violet irradiation by the described method, does not render the material less useful for intra-ocular use.

\section{Summary}

An apparatus designed for the sterilization of intra-ocular acrylic lens prostheses with ultra-violet rays (wavelength $2,537 \AA$ ) is described. Its efficiency has been demonstrated bacteriologically. It surpasses chemical methods of sterilization by avoiding toxic irritation of the eye. Postoperative inflammatory reaction, using acrylic lens prostheses sterilized with ultra-violet rays, was remarkably slight.

We are greatly indebted to Mr. J. van Wilgen, Philips Nederland N.V., Eindhoven, for his technical advice and for the construction of the quartz cuvette, and to Ir. J. Heijboer, Central Laboratory, T.N.O., Delft, for his analysis of polymethylmethacrylate irradiated with ultraviolet rays.

\section{REFERENCES}

BINKHORST, C. D. (1956a). Ophthalmologica (Basel), -, - .

BINKHORST, C. D. (1956a). Ophthalmolog

FröLICH, K. (1940). Kuntstoffe, 30, 267.

GILKES, M. J. (1956). Personal communication.

GoldmanN, H. (1955). In Saubermann (1955), p. 251.

Miller, H. A. (1953). Ann. Oculist. (Paris), 186, 312.

RIDLEY, H. (1952). British Journal of Ophthalmology, 36, 113.

RINTElen, F., and SAUBERMANN, G. (1956). Ophthalmologica (Basel), 131, 369.

SAUBERMANN, G. (1955). Ibid., 129, 247.

SCHARF, J. (1955). Ber. dtsch. ophthal. Ges. Heidelberg, 59, 222.

SCHRECK, E. (1955). Ibid., 59, 212.

Strampelli, B. (1955). Atti 41 Congr. Soc. oftal. ital., Bologna, 1955, 15, 427.

WILGEN, J. vaN (1955). Pharm. Weekbl., 90, 645. 